\title{
Metastatic Nasopharyngeal Keratinizing Squamous Cell Carcinoma
}

National Cancer Institute

\section{Source}

National Cancer Institute. Metastatic Nasopharyngeal Keratinizing Squamous Cell

Carcinoma. NCI Thesaurus. Code C156077.

A keratinizing squamous cell carcinoma that arises from the nasopharynx and has

metastasized to another anatomic site. 